\title{
The Importance of Digital Literacy in Social Media for Indonesian Netizen
}

\author{
Nadya Bela Pratiwi Jati Suwito ${ }^{1}$ and Zamzani ${ }^{2}$ \\ \{nadyabelapratiwi.2017@student.uny.ac.id ${ }^{1}$, zamzani@uny.ac.id ${ }^{2}$ \} \\ ${ }^{1,2}$ Universitas Negeri Yogyakarta, Indonesia
}

\begin{abstract}
Social media is a powerful tool for updating knowledge, news, and events that occur faster than television. The importance of digital literacy is a powerful stick for fighting rampant social media crime. There are many ways to prevent bad things from happening to social media users. The purpose of this article is to explain the importance of digital literacy for the general public, especially Indonesia. The recent incident with junior high school students was a sad portrait of social media. Evil comments seem to be a natural thing found in every news about them. The lack of attitude in cyberspace is the homework of today's generation. Things like this are not only in Indonesia, almost all the world experiences it and must be reminded often that the polite and polite attitude in the world can be applied. Low awareness of the "code of ethics" social media becomes a complex problem and the need for learning and early application to the current generation in particular. This article uses documentation research and reviews online news content about events on social media. The result is that people, Indonesia in particular, are still not very good at dealing with viral things on the internet.
\end{abstract}

Keywords: social media, digital literacy, Indonesian netizen

\section{INTRODUCTION}

Social media in the digital era has become a normal thing for people today. The demand to keep up-to-date about the news that often changes makes people have to follow in order not to miss the news and become less updated. Social media is like basic human needs besides clothing, food, and shelter. The community often expresses their opinions by reading or seeing news or events on social media without tracing deeper into the supporting facts. This is what can be called a lack of development of social media.

One way to be smart when using social media is to build a foundation of digital literacy in oneself and be applied according to its function. Digital literacy is basically the ability to understand and use information in the network (online). Therefore this study wants to discuss more deeply about the importance of digital literacy in socializing the media. Furthermore, this research will answer a core question about how important digital literacy is in social media for Indonesian internet citizens who aim to explain the importance of the role of digital 
literacy in acting on social media. A wise attitude that must be applied in social prayer is the key to not being easily carried away by uncertain news flow.

The study was also inspired by a study from Lee [1] about "Fake news, phishing, and fraud: a call for research on digital media literacy education beyond the classroom" that he said was the biggest threat in the digital era today where threats looks big but not visible. This is a mistake when addressing a message and information without tracing trusted sources and disseminating information without knowing the place. The contribution that should be made by communication researchers in particular is to broaden the scientific focus of media literacy and digital to the older adult population.

In order to realize the wishes of communication researchers out there, it is better to briefly explain about social media and its advantages. Social media is defined as an internet-based application service that allows people to create profiles in bordered systems, connect and reconnect with family members, friends, coworkers, acquaintances and make new friends through a list of friends already on their profiles and others, see and navigate the catalog or list of their connections and those made by others in the system [2]. The term social media or social networking sites are often used interchangeably and the concept of social media is similar to computer networks, where computers on the network are connected to one another through cables that show the relationship between them.

Social media has taken control or control of them in marketing and public relations by sending them to individuals and communities who create profiles, share, consume blogs, tweets, etc. According to Tim Weber [3] BBC Business Editors stated that right now, one smart tweet, an ingenious blog post, a devastating video and forwarded to hundreds of friends with a single click can increase / grow products or businesses and also have a tendency killing a product or damaging the company's stock price and inheritance that has long been built. Based on Forrester Research data that $75 \%$ of internet users use "social media" in the second quarter of 2008 by joining several social networks, reading blogs, or contributing to review shopping sites [4]. Based on that fact it can be said that a significant increase from $56 \%$ in 2007.

People change their behavior, habits, traditions and communication styles when spending more time on the screen, physical absence from society, reducing face-to-face communication and facing many health problems [5]. However, people prefer to use social media, because they get many uses such as achieving innovation easily, eliminating / suppressing feelings of loneliness, sharing and defending opinions [5], communicating and exchanging information socializing, make fun of, have a sense of every time in every place [5], be attentive, calculated and have a reputation etc. [5]. Because the use of social media among adolescents and middleaged people increases with time, indications of the results and importance of communication in this channel are important subjects for social science.

Negative impact is also unavoidable when discussing social media. Some examples of social media that are not good are played if it is not wise to use, for example on blogs, twitter, facebook, and Google+, it takes a lot of time to prepare content, upload results must be promoted through various other sites, uploads are very fast stacked with content new, twitter cannot make someone upload easily accessible in searches, adding followers can be a slow and difficult process, privacy issues, must change page views frequently, users are not good at using them, and nothing unique than on other sites [6].

Media literacy is a call for a common sense approach to understanding how to discuss communication, processes that give rise to meaning, and the nature of the media. However, the method of analysis must be based on systematic inquiry aimed at consensus on observable data. [7]. Media literacy is needed in preventing and dealing with the problems of social media 
today. It has been proven that ordinary children and adolescents use social medicine as a means of entertainment. Social media plays an important role in the development of democracy, cultural participation, and social. Therefore knowledgeable workers must be wise in using, manipulating, and creating information by relying on the internet [8].

Some opinions about digital literacy that have been distinguished according to the understanding of experts, for example, according to Hague and Payton [9] digital literacy means having access to a variety of cultural practices and sources that can be applied to digital tools. This capability is useful for creating and sharing meanings in a variety of modes and formats in order to communicate effectively and understand the ways and timing of using digital technology to support this process. Martin [9] understands that digital literacy is an individual's awareness, ability, and attitude in order to properly use digital tools and facilities to operate digital resources to the maximum in order to build new knowledge, make media expressions, and communicate with others in context- certain context. Buckingham believes that digital literacy means understanding culture [10].

In short, it can be understood that digital literacy is a place to build wise, intelligent and critical characters in using, understanding, and responding to the use of digital tools online in particular. Digital literacy is also needed so that the use of social media develops and has a good impact on society at large. Under the term "digital literacy" there are five types of literacy developed in it, the five types are photo-visual literacy, reproductive literacy, branching literacy, information literacy, and socio-emotional liters [9].

\section{METHOD}

This type of research is qualitative research that observes phenomena that exist in society and tries to understand the situation that exists in the environment [11]. To answer the main question in this study, researchers have prepared online documents that can be used as an example of the attitude of social media in the current digital era. This online document is in the form of a summary of the news about abuse that took place in Pontianak in early April 2019. The results expected by the researchers are to gather some samples of society that are not wise in responding to news that is viral on the internet. Examples of the usual news responses found in the comments column of a story are written and uploaded. After finding a number of samples needed, the discussion section will answer the importance of digital literacy in handling "less wise" responses in the news.

\section{RESEARCH AND DISSCUSION}

Beginning in April 2019, there was a furor on the internet about the violence experienced by junior high school students in Pontianak with the initials A. Briefly A experienced violence by a group of high school students after they clashed an argument in the Facebook comment column. One of the high school students did not receive the writing of his cousin brother A and one of the high school students coming to A's house to lure his cousin A's sister out but that didn't happen and finally A and the high school students were fighting. The news began to spread and spread to viral on social media twitter and the details about the chronology of the fight were far more sadistic than the facts that had been proven after being examined by the hospital. Because the facts are not necessarily true which have spread very quickly on the internet, resulting in the emergence of the \#JusticeforAudrey hashtag and the signing of the petition so that the perpetrators of violence are punished according to their mistakes [12].

The overwhelming response from the public using social media made this case very quickly handled by the police and was the center of attention by the president and several 
neighboring countries. Evil comments have also been sent to the perpetrators of violence who after being investigated were not as cruel as they were reported. Lapse of a week later, it turns out the fact revealed that Audrey or A did not experience acts of violence as reported and the victims were fine.

The news slapped many faces of internet citizens who initially supported Audrey and eventually became a regret and confused about how to do this case. The resentment of social media users flocked to find evidence that the victim was also a perpetrator of verbal abuse on Facebook by showing proof of some of the victim's nasty comments.

After all the evidence and facts are revealed, the community starts clever to choose who is worthy of defense and not. Like the speed with which this case is viral, so quickly this case has begun to dim and may be ignored by society. Many also stated that they wanted to withdraw the signature that had been done in the petition for the movement of the hashtag.

The difficulty of being wise in social media is indeed very reasonable. This fairness is based on the fact that every human being has a brief emotion to capture an event without seeking the truth quickly. Because basically digital literacy has three (3) main dimensions that need to be applied to every social media user [9], namely, the first cognitive dimension relating to critical thinking, evaluation, and making cycles in dealing with digital information, both social dimensions - emotional which requires the involvement of the ability to use the internet responsibly for socializing, communicating, and learning, the last dimension is the technical dimension which usually has technical and operational skills to use ITK in learning and daily activities.

Cases that occur above are also often found in various countries. An example is scam and phishing in the US which often occurs in adults [1]. Lack of education or knowledge about personal data protection and attitude to handling online fraud. There is another concern from Ford (2018) about technological developments that are very fast and result in a lack of readiness to use them [13]. Ford gave an example with a young man who saw hip hop videos on his computer. The video discusses money, friends and cars. According to him, such videos could have accidentally triggered post-traumatic stress for other teens who have been sexually abused or involved in sex trafficking. According to him, the dissemination of such content cannot be stopped, but can be addressed with a tool called digital literacy. Another example presented by Snyder and Prinsloo (2008) describes what happens if the practice of digital communication functions, dysfunctions, and takes on new and regulatory functions in South Africa, Brazil, Greece and Australia [14]. They say they have found a new understanding of the relationship between young people's digital media use and literacy practices in many dimensions of their lives. Studies have observed a variety of digital literacy practices with practice and according to geographical location, socio-economic status, gender, and culture. One good example was put forward by Slay and Dalvit (2008) who explained the direct impact of digital literacy and internet connectivity on poverty alleviation in South African village communities [15]. They explained that examples of areas in South Africa such as Dwesa are not isolated village examples, but with the willingness to learn ICT and digital literacy properly and correctly the impact seen will be quickly seen and the benefits will be felt in that environment only lack of access that makes the project this is difficult to penetrate all circles.

The case in Indonesia is more about the attitude that must be taken when socializing media and responding to a news that is uncertain even though from a trusted news source. While the case examples are more about the application of digital literacy and the impact received by the community. 


\section{CONCLUSION}

The digital age that is filled with the use of the internet, especially social media, makes news quickly spread quickly and often without critical thinking. As members of the digital age community, we must know how to deal with the digital era in using social media. Being a critical and observant society in acting in cyberspace is something that is currently required to be done so that it is not carried out negatively by negative people.

\section{REFERENCE}

[1] N. M. Lee, "Fake news, phishing, and fraud: a call for research on digital media literacy education beyond the classroom," Commun. Educ., vol. 67, no. 4, pp. 460-466, 2018.

[2] T. L. Ellison, "Counter-Storytelling vs . Deficit Thinking around African American Children and Families, Digital Literacies, Race, and the Digital Divide CounterStorytelling," vol. 53, no. 3, pp. 223-244, 2019.

[3] C. Jeremiah, "Temporary social media," Eur. J. Comput. Sci. Inf. Technol., vol. 4, no. 6, pp. 32-36, 2016.

[4] A. M. Kaplan and M. Haenlein, "Users of the world, unite! The challenges and opportunities of Social Media," Bus. Horiz., vol. 53, no. 1, pp. 59-68, 2010.

[5] T. Durukan and I. Bozaci, "Social Media And Consumer Communications In Crisis Periods," Br. J. Mark. Stud., vol. 2, no. 26, pp. 1-8, 2014.

[6] H. M. Bik and M. C. Goldstein, "An Introduction to Social Media for Scientists," PLoS Biol., vol. 11, no. 4, p. e1001535, 2013.

[7] E. Gaines, "Media Literacy and Semiotics Semiotics and Popular Culture," 2010.

[8] T. Koltay, "The media and the literacies: Media literacy, information literacy, digital literacy," Media, Cult. Soc., vol. 33, no. 2, pp. 211-221, 2011.

[9] W. Ng, "Can we teach digital natives digital literacy?," Comput. Educ., vol. 59, no. 3, pp. 1065-1078, 2012.

[10] D. Buckingham, "Defining Digital Literacy: What Do Young People Need to Know," Digit. literacies Concepts, policies Pract., pp. 73-89, 2008.

[11] S. Sarosa, Penelitian Kualitatif: Dasar-Dasar. Jakarta: PT Index, 2012.

[12] H. Fadhil, "Berawal dari Bully di Medsos, Begini Kronologi Kasus Audrey," https://news.detik.com/berita/d-4506079, 2019.

[13] C. A. Ford, "Equity and Digital Literacies: Issues of Access, Ethics and Engagement in a Youth Community Setting," Lang. Lit., vol. 20, no. 3, pp. 67-72, 2018.

[14] I. Snyder and M. Prinsloo, "Young people's engagement with digital literacies in marginal contexts in a globalised world," Lang. Educ., vol. 21, no. 3, pp. 171-179, 2007.

[15] H. Slay and L. Dalvit, "Red or Blue? The Importance of Digital Literacy in African Rural Communities," pp. 675-678, 2008. 